Trivent Publishing

(C) The Authors, 2016

Available online at http://trivent-publishing.eu/

Series: Philosophy, Communication, Media Sciences

Volume: Communication Today: An Overview from Online Journalism to Applied Philosophy

\title{
The Serbian Daily Press on the Greek Crisis
}

\author{
Laura Spariosu
}

Department of Romanian Studies, Faculty of Philosophy, University of Novi Sad, Serbia laura.spariosu@ff.uns.ac.rs

\begin{abstract}
:
The aim of this paper is to research how Serbian daily newspapers inform on Greek crisis. The intention of the author is to analyse texts about this issue published in the online edition of daily newspapers Večernje novosti (nontabloid), Blic (semitabloid) and Kurir (tabloid), in the period from the $1^{\text {st }}$ to the $15^{\text {th }}$ of July 2015, according to a code list issued for journalistic text analysis that refers to: text length, journalistic genre, text authorship, cause of reporting, visual presentation, location, topic, subject, object, value context and headlines. The paper will question how the selected media present the event and what are the similarities and differences in the researched topic.
\end{abstract}

\section{Keywords}

Daily press; Greek crisis; Večernje novosti; Blic; Kurir.

This is an Open Access article distributed in accordance with the Creative Commons Attribution Non Commercial (CC-BYNC-ND 4.0) license, which permits others to copy or share the article, provided original work is properly cited and that this is not done for commercial purposes. Users may not remix, transform, or build upon the material and may not distribute the modified material (http://creativecommons.org/licenses/by-nc/4.0/)

DOI: $10.22618 /$ TP.PCMS.20164.349002 


\section{Introduction}

Critical discourse analysis (CDA) is a type of analytical discourse research that primarily studies the way social power abuse, dominance, and inequality are enacted, reproduced, and resisted by text and talk in the social and political context. With such dissident research, critical discourse analysts take explicit position, and thus want to understand, expose, and ultimately resist social inequality. ${ }^{1}$ Nowadays, CDA is not so much a direction, a school, or specialization next to the many other "approaches" in discourse studies. Rather, it aims to offer a different "mode" or "perspective" of theorizing, analysis, and application throughout the whole field. We may find a more or less critical perspective in such diverse areas as pragmatics, conversation analysis, narrative analysis, rhetoric, stylistics, sociolinguistics, ethnography, or media analysis, among others ${ }^{2}$.

The undeniable power of the media has inspired many critical studies in many disciplines: linguistics, semiotics, pragmatics, and discourse studies. Traditional, often content analytical approaches in critical media studies have revealed biased, stereotypical, sexist or racist images in texts, illustrations, and photos. ${ }^{3}$ In that way, there are many studies and authors who could be mentioned: Hall et all. ${ }^{4}$ within the framework of the cultural studies paradigm, Agger. ${ }^{5}$ and Collins et all., ${ }^{6}$ for introduction to the critical work of cultural studies, Davis and Walton ${ }^{7}$ for earlier critical approaches to the analysis of media images, and Fairclough ${ }^{8}$ for CDA that is related to the critical approach of cultural studies, focusing on the linguistic "tools" such as the analysis of transitivity in syntax, lexical structure, modality, and speech acts. Furthermore, van Dijk ${ }^{9}$ applies a theory of news discourse in critical studies of international news, racism in the press, and the coverage of squatters in Amsterdam.

\section{Context of media ${ }^{10}$}

Media discourse refers to interactions that take place through a broadcast platform, whether spoken or written, in which the discourse is oriented to a non- present reader, listener or viewer. Though the discourse is oriented towards these recipients, they very often cannot make instantaneous responses to the producer(s) of the discourse, though increasingly this is changing with the advent of new media technology, as we shall explore. Crucially, the written or spoken discourse itself is oriented to the readership or listening/viewing audience, respectively. In other words, media discourse is a public, manufactured, on-record, form of interaction. It is not ad hoc or spontaneous (in the same way as casual speaking or writing is); it is neither private nor off the record. Obvious as these basic characteristics may sound, they are crucial to the investigation, description and understanding of media discourse. ${ }^{11}$

\footnotetext{
${ }^{1}$ T. A. van Dijk, "Critical Discourse Analysis“, in The Handbook of Discourse Analysis, ed. D. Schiffrin, D. Tannen, H. E. Hamilton (Malden, Massachusetts, USA: Blackwell Publishers Ltd, 2005), 352-371.

2 T. A. van Dijk, in The Handbook of Discourse Analysis, ed. D. Schiffrin, D. Tannen, H. E. Hamilton, (Blackwell Publishers Ltd, Malden, Massachusetts, USA, 2005), 352-371.

${ }^{3}$ Ibidem.

${ }^{4}$ Culture, Media, Language, ed. S. Hall et all. (London: Hutchinson, 1980).

${ }^{5}$ B. Agger, Cultural Studies as Critical Theory (London: Falmer Press, 1992).

${ }^{6}$ Media, Culture and Society, ed. R. Collins and all. (London, Sage, 1986).

${ }^{7}$ Language, Image, Media, ed. H. Davis and P. Walton (Oxford: Blackwell, 1983).

${ }^{8}$ N. L. Fairclough, Media Discourse (London: Edward Arnold, 1995).

${ }^{9}$ T. A. van Dijk, News as Discourse (Hillsdale, NJ: Erlbaum, 1988).

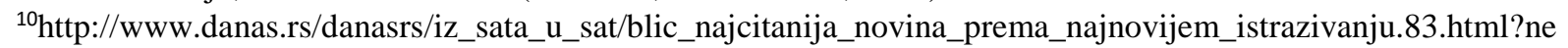
ws_id=84193 (accessed October 25, 2015).

${ }^{11}$ A. O'Keeffe, "Media and discourse analysis“, in The Routledge Handbook of Discourse Analysis, ed. J. Gee and M. Handford (London: Routledge, 2011), 441-454.
} 
Večernje novosti „Evening News” is a Serbian daily newspaper. Founded in 1953, it quickly grew into a high-circulation daily. Novosti (as most people call it for short) also employs foreign correspondents spread around 23 national capitals around the globe.

It first appeared on stands on October 16, 1953 edited by Slobodan Glumac who set the newspaper's tone for years to come. Housing an extensive network of journalists and contributors, the paper reported and commented on various issues and events according to its mantra: fast, brief and clear. In mid-1980s Novosti got a big scoop by publishing the old files of the State Commission for War Crimes, which shed new light on Austrian president Kurt Waldheim's involvement in war crimes during the World War II. The file F-25572 dated November 17, 1947, which Novosti published for the first time gave new details of Waldheim's whereabouts in Yugoslavia during the war.

Though it is one of the region's longest enduring newspapers, it is also remembered for its association with the regime of Slobodan Milošević. Loyalty to his regime was the most important job requirement at the paper in this period. Through party installed editor-in-chief, Milošević was able to control the paper and use it to espouse propaganda.

Today Večernje novosti is an independent media with majority private property (stock company with $30 \%$ state ownership, while $70 \%$ of the shares held by small shareholders).

Blic is a semi-tabloid daily newspaper in Serbia.

Founded in 1996, Starting out, Blic was a typical stripped-down tabloid with short and simple stories, as well as a lot of entertainment content. Its first issues were circulated in 50,000 copies per day. Unlike Večernje novosti, this newspaper was not the one supporting the regime of Slobodan Milošević.

In November 1996, when local municipal elections were held across Serbia and Milošević lost and refused to recognize the results, the oppositional parties organized a huge outpouring of street protests. Blic capitalized on this to further its position on the market through fair coverage of the events ignored by the Milošević regime-controlled media. The decision turned out to be a business winner in the short term as circulation rapidly grew to 200.000 copies per day, but it also drew the ire of the Milošević authorities.

In the circumstances when state media made virtually no mention of the protests and the reporting of the independent media was insufficient on the subject, Blic made a gutsy decision to devote a sizable part of its paper every day to the protests. The Milošević regime lashed back immediately - it restricted Blic's access to print and distribution facilities as the state printing house refused to print any more than 80.000 copies of the paper. The problem first appeared when it came time to print the 29 November 1996 holiday 4-day issue (FR Yugoslavia at the time still celebrated the old SFR Yugoslavia's Day of the Republic) as the state-owned Borba printing facility informed Blic staff that it's not able to print the holiday issue in the requested 235.000 copies ,due to technical reasons" and instead offered to print about a third of that. The holiday issue still appeared on newsstands in projected circulation as some of it got printed at Borba and the rest in privately owned ABC Produkt. However, the issue that appeared was a complete whitewash, abandoning the paper's new concept and going back to entertainment and frivolity. Forty three journalists employed at Blic immediately publicly distanced themselves from the issue.

From 2004 Blic is owned by Ringier Axel Springer Media AG, a joint venture between Ringier media corporation from Switzerland and Axel Springer $A G$ from Germany.

Many studies readership of printed media classified Blic as one of the most popular daily newspapers in Serbia, often perceived by its readers as a pro-European newspaper, providing brief and clear information, although there are some dispute about these researches, claiming that are biased. Also, website of Blic is one of the most visited internet sites in Serbia.

Kurir is a high-circulation daily tabloid published in Belgrade. Its first issue appeared on May $6^{\text {th }}$, 2003. This newspaper often publishes sensational stories, being often criticized by state authorities and media organizations. Although the paper heavily relies on celebrity gossip, it also achieved political influence. 


\section{Corpus, method and analysis}

The aim of this paper is to research how Serbian daily newspapers inform on Greek crisis. It is the intention of the author to analyse texts about this issue published in the online issue of daily newspapers Večernje novosti (non-tabloid) - 27 texts, Blic (semi-tabloid) - 120 texts and Kurir (tabloid) - 38 texts, in the period from 1st to 15th July 2015, according to a code list issued for journalistic text analysis. All the texts were extracted from online archive of the abovementioned newspapers. Speaking of the above-mentioned, the following aspects will be analysed: text length, journalistic genre, text authorship, cause of reporting, visual presentation, location, topic, subject, object, value context and headlines. The paper will question how the selected media present the event and what are the similarities and differences in the researched topic.

\section{Research results}

\section{A. Text length}

This category takes into consideration the length of journalistic text - if there is a short text (a few sentences), medium sized text (not longer than $1 / 3$ of page), or a long text (half page or longer).

Based on research results, it is shown that of 27 texts in Večernje novosti, the most - $18(66,66 \%)$ are long, $6(22,22 \%)$ are medium sized, 3 texts $(11,11 \%)$ are short. In Blic of 120 texts $75(62,5 \%)$ are long, $30(25 \%)$ are medium sized, 15 texts $(12,5 \%)$ are short. In Kurir of 38 texts $15(39,47 \%)$ are long, $12(31,57 \%)$ are medium sized, 11 texts $(28,94 \%)$ are short.

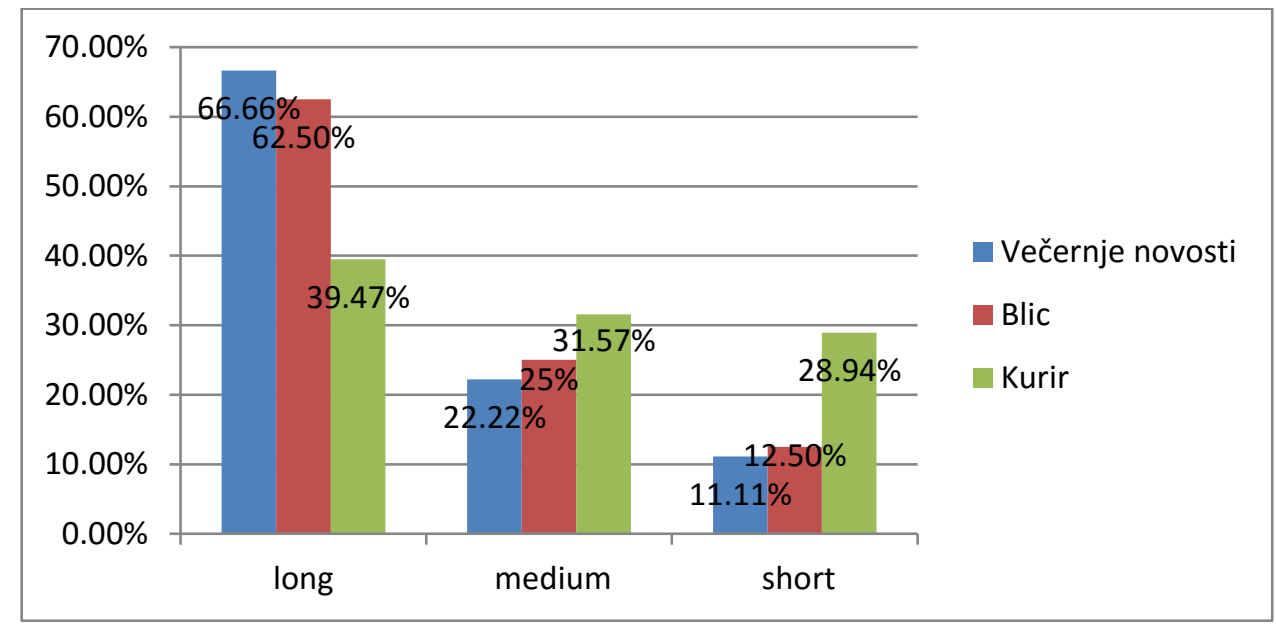

Fig. 1. Text length

\section{B. Journalistic genre}

In all three daily newspapers the most frequent journalistic genre is article - $15(55,55 \%)$ in Večernje novosti, 67 (55,83\%) in Blic, 27 (71,05\%) in Kurir. Aside from articles, there are 10 reports (37,03\%), 1 news $(3,70 \%)$ and 1 declaration $(3,70 \%)$ in Večernje novosti, 35 news $(29,16 \%)$ and 18 reports (15\%) in Blic, 7 news $(18,42 \%)$ and 4 reports $(10,52 \%)$ in Kurir. Presence of simple, "trivial" forms (articles, reports, news, declarations) instead of complex contents (reportage or "hybrid" forms) shows insufficient journalistic effort to report on this topic in more attractive way. 


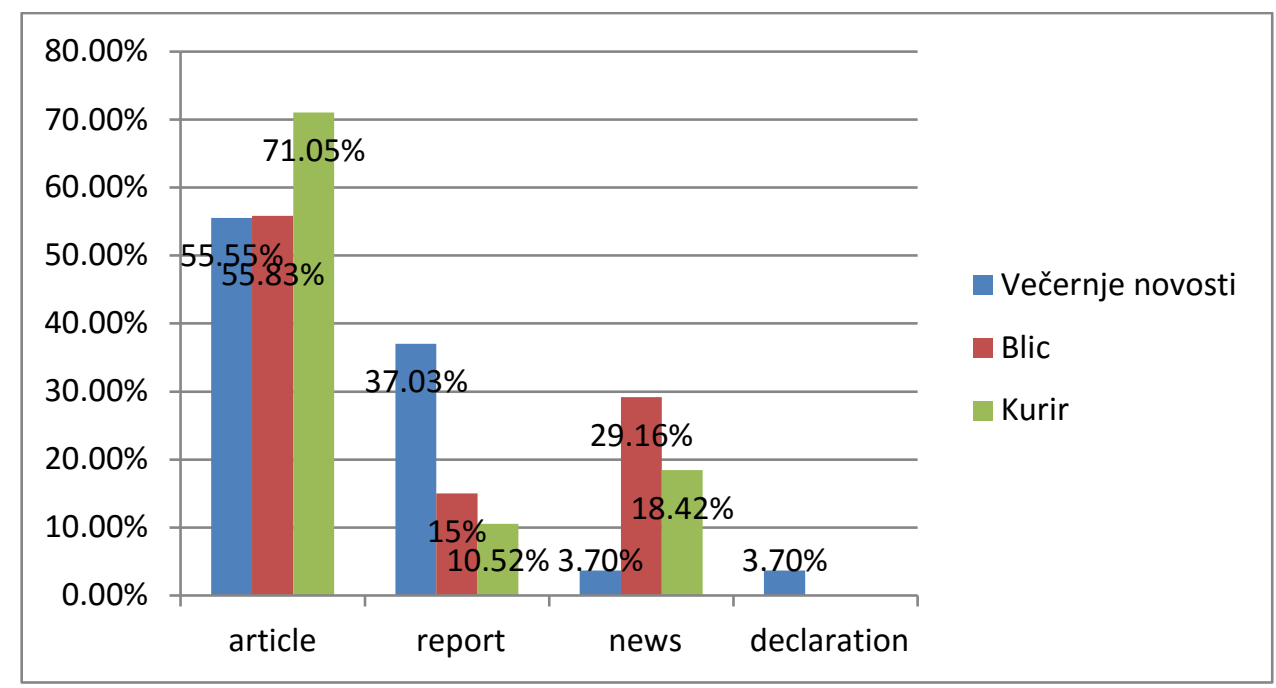

Fig. 2. Journalistic genre

\section{Text authorship}

In all three newspapers, analyzed texts are mostly taken from a news agency -15 texts $(55,55 \%)$ in Večernje novosti, 85 texts $(70,83 \%)$ in Blic, 36 texts $(94,73 \%)$ in Kurir. 6 texts $(22,22 \%)$ in Večernje novosti are signed by the author (full name and surname), 5 texts $(18,51 \%)$ are signed by the author`s name initial and full surname, 1 text $(3,71 \%)$ is signed by the author's initials. In Blic there are 12 texts $(10 \%)$ signed by the author's name initials and full surname, 10 texts $(8,33 \%)$ are signed by the author`s initials, 5 texts $(4,16 \%)$ are taken from another mass-media. In Kurir there is 1 text $(2,63 \%)$ signed by the author`s full name and surname and 1 text $(2,63 \%)$ signed by the Editorial Board. Great number of unoriginal texts, taken from news agencies, clearly indicates lack of journalistic engagement and low interest related to the researched topic.

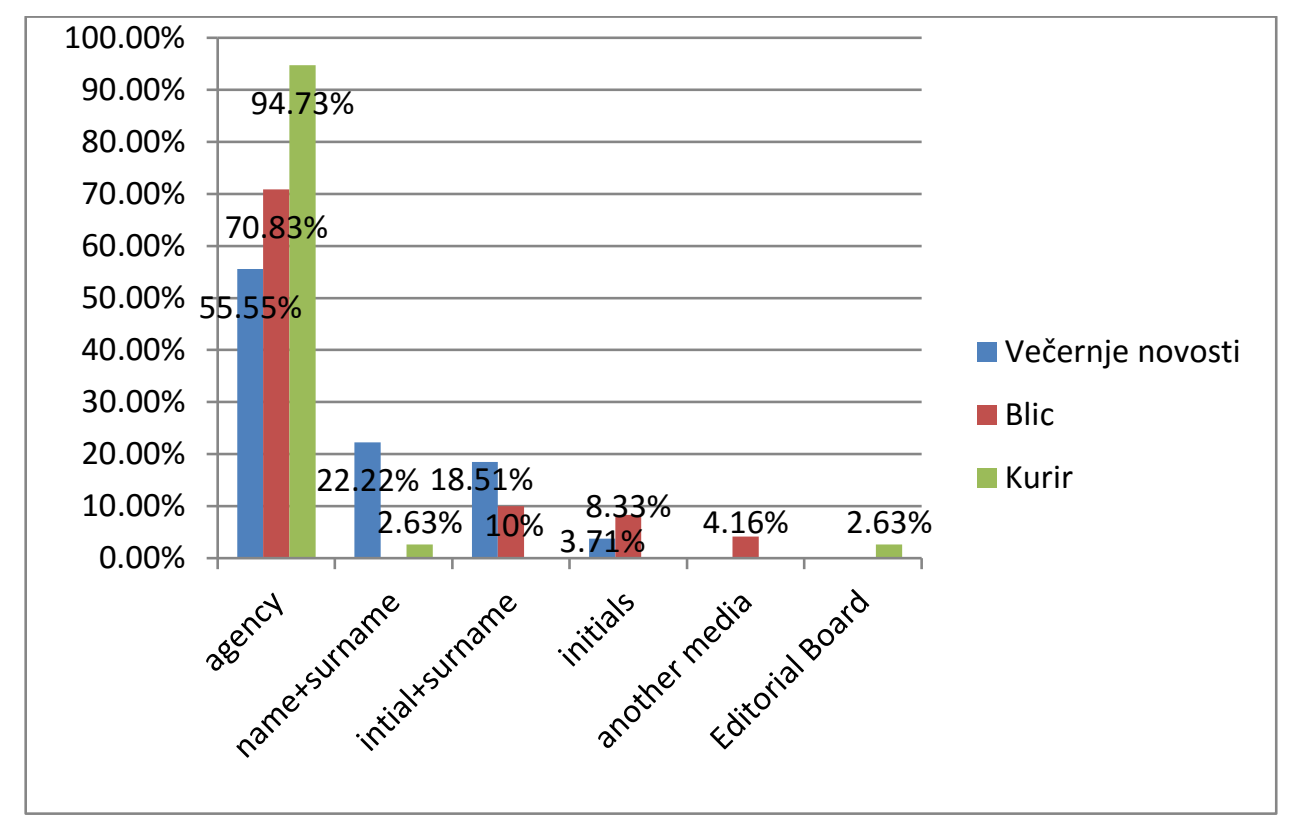

Fig. 3. Text authorship 


\section{Cause of reporting}

As for the cause of reporting, the analysis showed that all three newspapers every time reported on actual events - 25 times (92,59\%) Večernje novosti, 120 times (100\%) Blic, 38 times (100\%) Kurir. Also there are 2 media initiatives $(7,40 \%)$ registered in Večernje novosti. The absence of media initiatives is also an indicator of low journalistic engagement and lack of dedication in reporting on this subject.

\section{E. Visual presentation}

In all three newspapers, texts are always followed by photo - 35 times $(92,59 \%)$ in Večernje novosti, 119 times $(99,16 \%)$ in Blic, 36 times $(94,73 \%)$ in Kurir. Usually, there are photos of the prime ministers and finance ministers. Also, there are 2 texts $(7,4 \%)$ followed by photo and caricature in Večernje novosti, 1 text $(0,83 \%)$ followed by photo and chart in Blic and 2 texts $(5,26 \%)$ followed by both photo and video in Kurir.

\section{F. Location}

In Večernje novosti the most frequent location is Athens (Greece) - 16 times $(66,66 \%)$, then Brussels (Belgium) - 5 timess (18,51\%), Berlin (Germany) - 2 times (7,4\%), Paris (France) - 2 times $(7,4 \%)$. Athens (Greece) is also the most frequent location in Blic - 70 times $(58,33 \%)$, then Brussels (Belgium) - 25 times (20,83\%), Berlin (Germany) - 10 times (8,33\%), Paris (France) - 8 times $(6,66 \%)$, Washington (USA) - 2 times $(1,66 \%)$, once about events in Wien (Austria) - 0,83\%, Luxembourg - 0,83\%, Helsinki (Finland) - 0,83\%, Moscow (Russia) - 0,83\%, Warsaw (Poland) $0,83 \%$. Kurir reported the most about events in Athens (Greece) - 24 times $(63,15 \%)$, Brussels (Belgium) - 4 times (10,52\%), New York (USA) - 3 times (7,89\%), Berlin (Germany) - 2 times (5,26\%), Moscow (Russia) - 2 times (5,26\%) and once about events in Paris (France) - 2,63\%, Warsaw (Poland) $-2,63 \%$, Sidney (Australia) $-2,63 \%$.

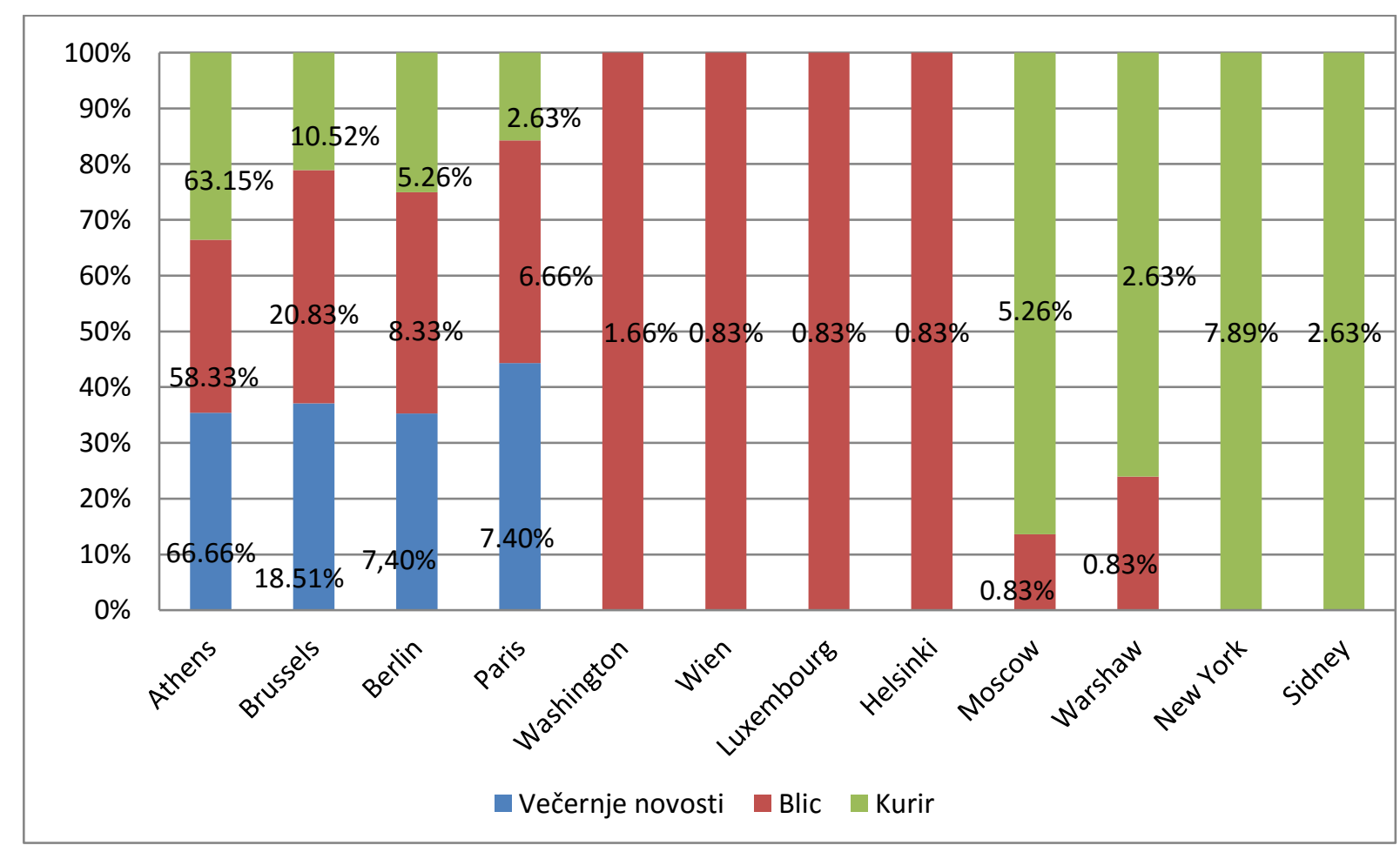

Fig. 4. Location 


\section{G. Topic}

All three newspapers every time reported on Greek crisis - 27 times (100\%) Večernje novosti, 120 times (100\%) Blic, 38 times (100\%) Kurir.

\section{H. Subject - who is speaking?}

The following subjects are speaking in Večernje novosti:

- representatives of the state bodies - $15(55,55 \%)$ : prime minister of Greece, Alexis Tsipras, German chancellor, Angela Merkel, finance minister of Greece, Euclid Tsakalotos, finance minister of Germany, Wolfganag Schäuble, former finance minister of Greece, Yanis Varoufakis;

- $\quad$ state bodies - 5 (18,51\%): Government and Ministry of Finance of Greece;

- representatives of the euro area member states - 2 (7,40\%): Jeroen Dijsselbloem, head of the Eurozone Finance Ministers' Group;

- citizens - 2 (7,40\%): people of Greece;

- international organizations - $1(3,70 \%)$; IMF;

- experts in the field of economy - 1 (3,70\%): Serbian expert Dragan Cvjetićanin;

- mass-media - 1 (3,70\%): Greek newspaper „Parapolitika“;

- journalists $-1(3,70 \%)$ : jorunalist of „Večernje novosti““.

The following subjects are speaking in Blic:

- representatives of the state bodies - 60 (50\%): president of Greece, Prokopis Pavlopoulos, prime minister of Greece, Alexis Tsipras, German chancellor, Angela Merkel, Austrian chancellor, Werner Faymann, prime minster of France, Manuel Valls, prime minister of Italy, Matteo Renzi, prime minister of Holland, Mark Rutte, prime minister of Slovakia, Robert Fico, prime minister of Poland, Ewa Racz, foreign minister of Belgium, Didier Reynolds, foreign minister of Luxembourg, Jean Asselborn, finance minister of Germany, Wolfgang Schäuble, finance minister of Greece, Euclid Tsakalotos, former prime minister of Greece, Antonis Samaras, former finance minister of Greece, Yanis Varoufakis, deputy of finance minister of Greece, Dimitris Mardas, member of the Parliament of Greece, Vangelis Meimarakis, Dmitry Peskov, press spokesman for the President of Russia, Vladimir Putin;

- representatives of the international organizations - 15 (12,5\%): Donald Tusk, president of the European Council, Jean Claude Juncker, president of the European Commission, Martin Schulz, president of the European Parliament, Joseph Leinen, member of the European Parliament;

- international organizations $-10(8,33 \%)$ : IMF;

- representatives of the euro area member states - 10 (8,33\%): Jeroen Dijsselbloem, head of the Eurozone Finance Ministers' Group;

- state bodies - 6 (5\%): Government of Greece, Government of the USA, Bundestag, Parliament of Finland, Ministry of Finance of Greece;

- citizens 6 (5\%): people of Greece;

- subjects in economy - 3 (2,5\%): Greek banks, Deutsche Bank;

- mass-media - 3 (2,5\%): BBC, Bild, Parapolitika;

- experts in economy $-2(1,66 \%)$ : Thomas Piketty, Jeffrey Sachs;

- representatives of the political parties - $1(0,83 \%)$ : Julia Klöckner, member of the Christian Democratic Union in Germany;

- rating agencies $-1(0,83 \%)$ : Fitch Ratings;

- journalists- 1 (0,83\%): New York Times` columnist, Paul Krugman;

- subjects in arts $-1(0,83 \%)$ : Greek director Costas Gavras. 
The following subjects are speaking in Kurir:

- representatives of the state bodies - 23 (60,52\%): president of France, François Hollande, president of Russia, Valdimir Putin, prime minister of Greece, Alexis Tsipras, German chancellor, Angela Merkel, prime minister of Poland, Ewa Racz, minister of Foreign Affairs of Belgium, Didier Reynolds, minister of Foreign Affairs of Russia, Sergey Lavrov, finance minister of Germany, Wolfgang Schäuble, finance minister of Greece, Euclid Tsakalotos, former prime minister of Greece, Antonis Samaras, former finance minister of Greece, Yanis Varoufakis, Dmitry Peskov, press spokesman for the President of Russia, Vladimir Putin;

- international organizations - 3 (7,89\%): IMF;

- representatives of the European institutions - 3 (7,89\%): president of European Commission, Valdis Dombrovskis, european commissioner for Economic and Financial Affair, Pierre Moscovici;

- $\quad$ subjects in economy - 2 (5,26\%): Greek banks;

- mass-media - $2(5,26 \%)$ : CNN, Guardian;

- journalists - 2 (5,26\%): American publicist William Engdahl, American journalist James Angelous;

- representatives of the political parties - 1 (2,63\%): Gregor Gysi, politician of the political party The Left in Germany;

- news agencies $-1(2,63 \%)$ : Reuters.

- representatives of the Catholic Church - 1 (2,63\%): the Pope Francis.

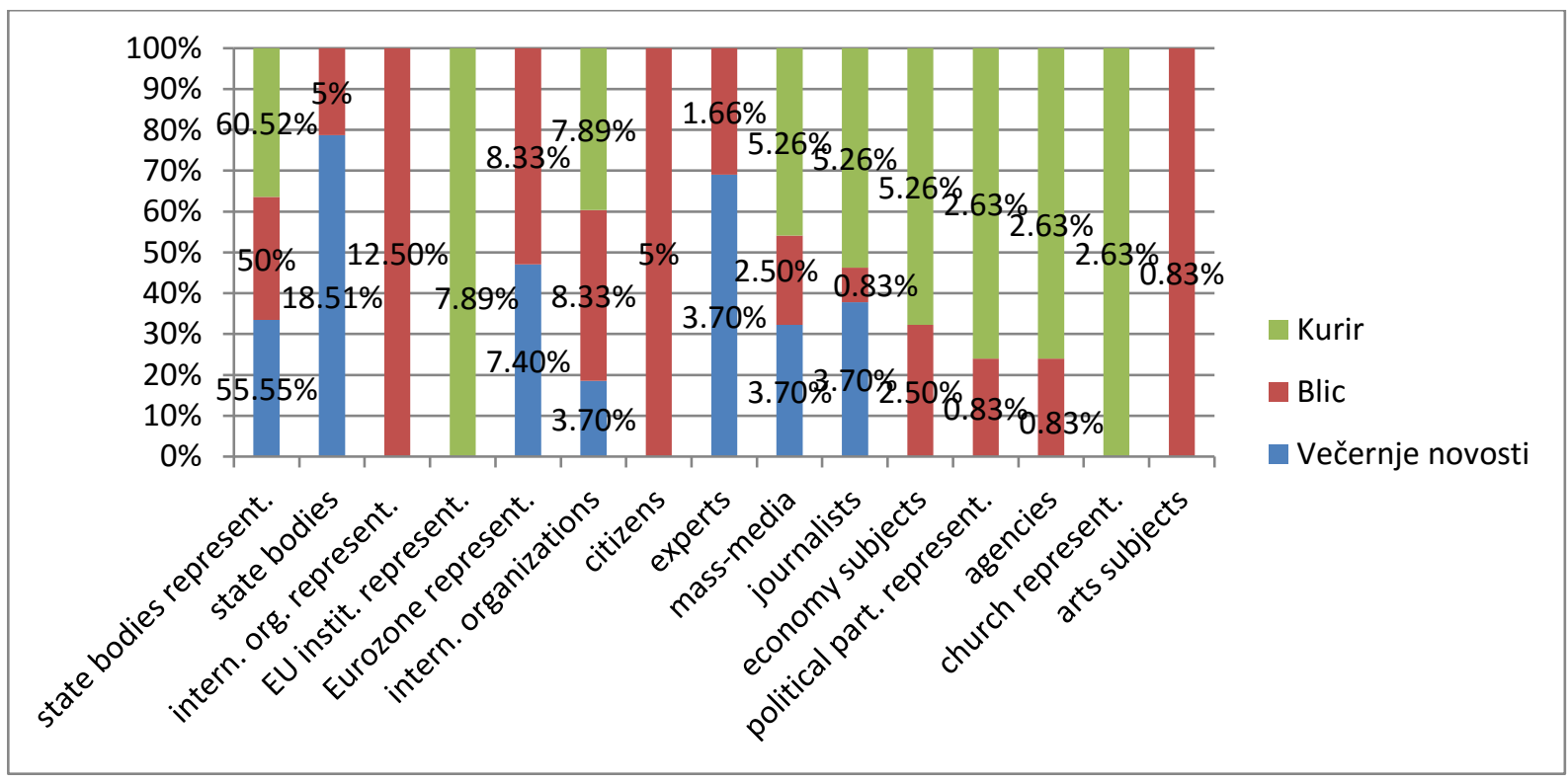

Fig. 5. Subject

\section{Object - of whom is it spoken?}

The following objects appear in Večernje novosti:

- state bodies - 10 (37,03\%): Government of Greece;

- representatives of the state bodies - 7 (25,92\%): prime minister of Greece, Alexis Tsipras, German chancellor, Angela Merkel, finance minister of Germany, Wolfganag Schäuble, former prime minister of Greece, Antonis Samaras;

- citizens - 6 (22,22\%): people of Greece;

- objects in economy - 3(11,11\%): Greek banks;

- mass-media - $1(3,70 \%)$ : BBC. 
The following objects appear in Blic:

- state bodies - 66 (55\%): Greek Government, German Government, Parliament of Greece, Bundestag;

- citizens - $26(21,66 \%)$ : people of Greece;

- representatives of the state bodies - 21 (31,81\%): president of France, François Hollande, prime minister of Greece, Alexis Tsipras, German chancellor, Angela Merkel, finance minister of Greece, Euclid Tsakalotos, former finance minister of Greece, Yanis Varoufakis;

- international organizations - 6 (5\%): IMF;

- representatives of the European institutions - $1(0,83 \%)$ : Mario Draghi, president of the European Central Bank.

The following objects appear in Kurir:

- state bodies - 18 (47,36\%): Government and Parliament of Greece;

- citizens - $13(34,21 \%)$ : people of Greece;

- representatives of the state bodies - 7 (18,42\%): prime minister of Greece, Alexis Tsipras, German chancellor, Angela Merkel, former finance minister of Greece, Yanis Varoufakis.

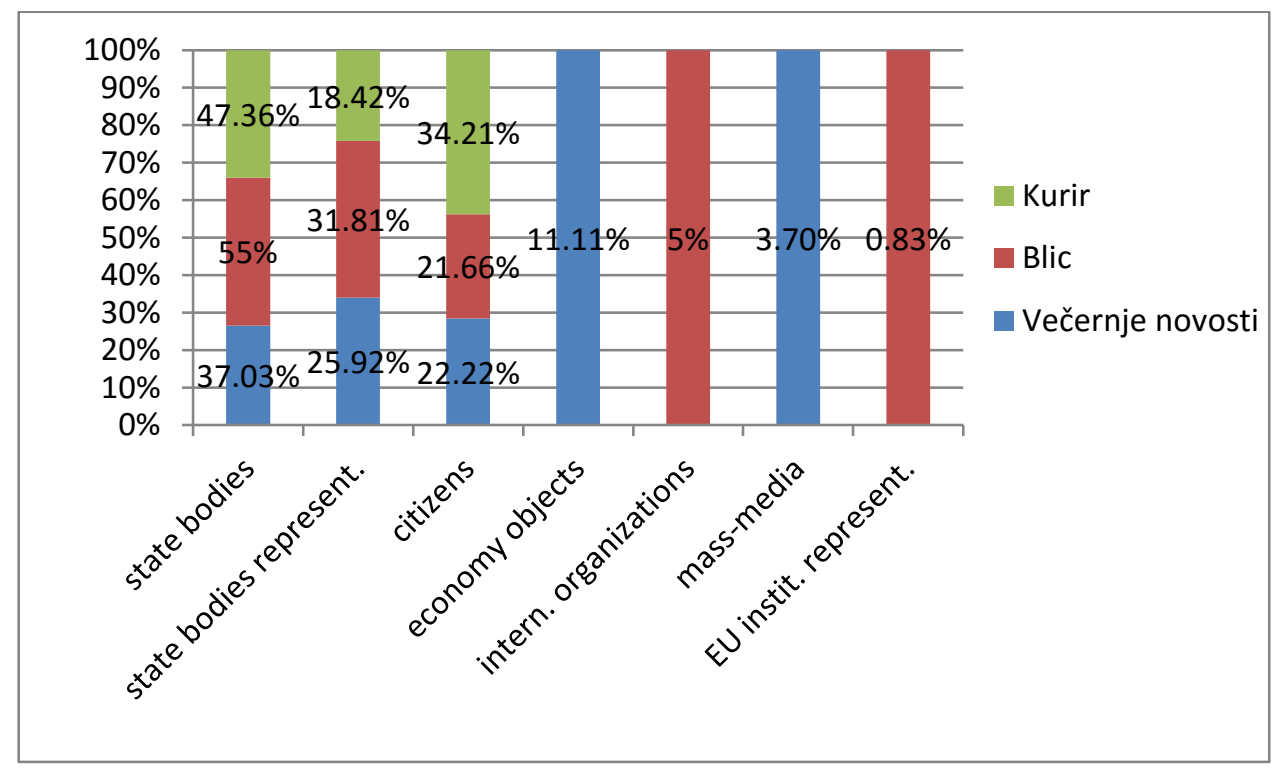

Fig. 6. Object

\section{J. Value context}

This category refers to subject's attitude towards object i.e. which is the context subject puts the object.

In all three newspapers value context is mostly neutral - 18 times $(66,66 \%)$ in Večernje novosti, 88 times $(73,33 \%)$ in Blic, 27 times $(27,05 \%)$ in Kurir. In the second place is positive, affirmative attitude - 7 times $(25,92 \%)$ in Večernje novosti, 20 times $(5,83 \%)$ in Blic, 8 times $(21,05 \%)$ in Kurir, while negative, confrontational attitude is the least registered: once $(3,7 \%)$ in Večernje novosti, 12 times $(10 \%)$ in Blic, 3 times $(7,89 \%)$ in Kurir. 


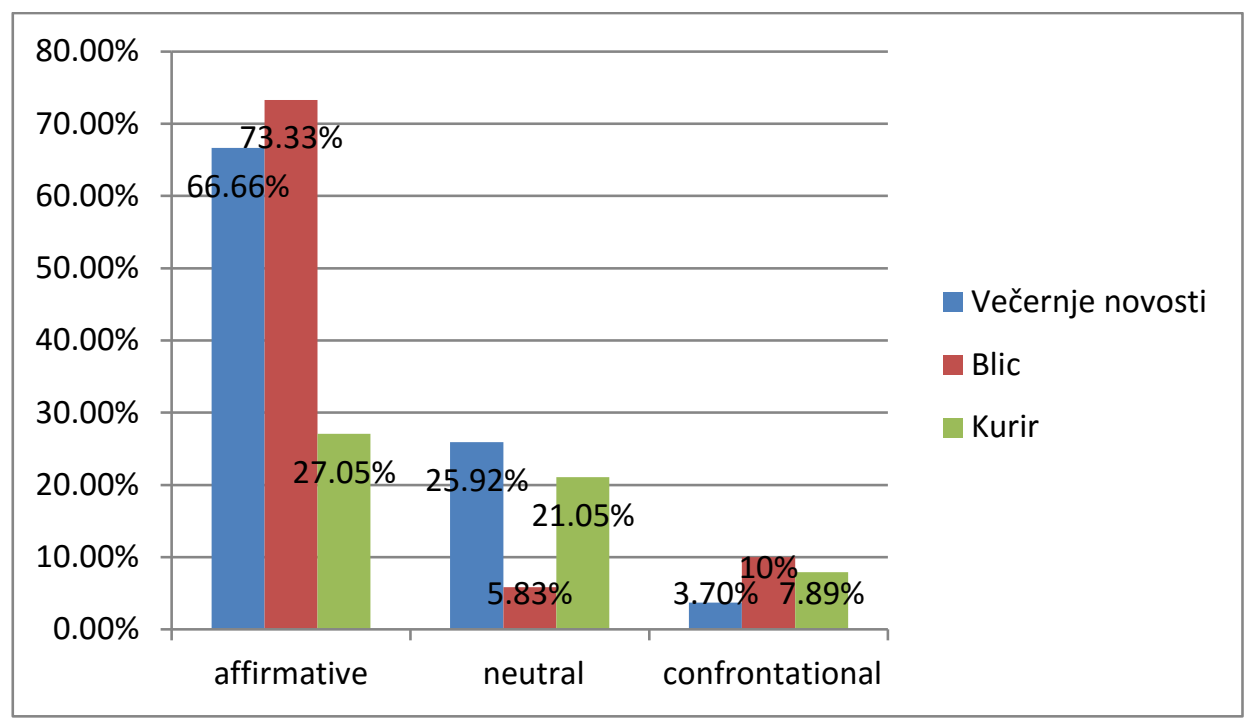

Fig. 7. Value context

\section{K. Headlines}

Headlines in all three newspapers are informative, real and non-metaphorical, every time in Večernje novosti and Blic, 36 times $(94,73 \%)$ in Kurir. Here are some examples: Javni sektor u Grčkoj štrajkuje, banke i u četvrtak zatvorene "Public sector in Greece on strike, banks closed on Thursday" (Večernje novosti); Koji su mogući epilozi grčke krize? "Which are the possible epilogues of Greek crisis?" ( Blic); Atina podnosi nov predlog o dugu "Athens submitted a new proposal on debt" (Kurir). Also, there are 2 nonmetaphorical headlines in Kurir: Ciprasova tupa sablja [Tsipras` blunt saber]; Varufakis je trojanski konj zapadnih bankara i grckkih oligarha [Varoufakis is the Trojan horse of Western bankers and Greek oligarchs].

\section{Conclusions}

Although the number of analyzed texts varies - 27 in Večernje novosti, 120 in Blic, 38 in Kurir and despite the fact that there are three different types of daily newspapers - nontabloid (Večernje novosti), semitabloid (Blic) and tabloid (Kurir), similarities dominate the research results.

In all the newspapers most texts are long, medium sized texts are in the second place, short texts are in the third place. Also, the most frequent journalistic genre is article. Aside from article as journalistic genre, there are also news and reports in all three newspapers and declarations in Večernje novosti. Presence of simple forms (articles, reports, news, declarations) instead of complex contents (reportage or "hybrid" forms) shows insufficient journalistic effort to report on this topic in more attractive way. In all three newspapers most texts are taken from a news agency. Great number of unoriginal texts, taken from news agencies, clearly indicates lack of journalistic engagement and low interest related to the researched topic. Still there are texts signed by the author (full name and surname in Večernje novosti and Kurir), texts signed by author`s initials (registered in all three newspapers) and texts taken from another mass-media (Blic). In all three newspapers, texts are always followed by photo and all three newspapers reported on actual events - Greek crisis. Although there are 2 media initiatives registered in Večernje novosti, the absence of those is also indicator of low journalistic engagement and lack of dedication in reporting on this subject.

Bearing in mind the fact that the focus was on Greek crisis, naturally, the most frequent locations are European capital cities Athens (Greece), then Brussels (Belgium), Berlin (Germany) and Paris (France). Aside from these, Blic and Kurir reported on events in the USA and Moscow (Russia). On this topic usually speak representatives of the state bodies (prime ministers and finance ministers), representatives of EU institutions, experts in economy and finance, representatives of political parties, 
other mass-media, agencies and journalists. In the role of object there are usually state governments (Greek Government the most), citizens (Greek people) and representatives of the state bodies. Attitude of subject towards object in all three newspapers is mostly neutral, less positive, the least confrontational, negative. Also, as a common feature could be identified lack of sensationalism, with headlines that are informative, real and non-metaphorical. Still there are 2 metaphorical headlines registered in tabloid daily newspaper Kurir.

\section{References}

Agger, B. Cultural Studies as Critical Theory. London: Falmer Press, 1992.

Barović, V. "Medijska etika i izveštavanje u kriznim situacijama" [Media ethics and reporting in crisis situations]. In Filozofija i mediji. Zbornik radova, ed. H. Jurić and S. Alić, 159-166. Zagreb: Hrvatsko filozofsko društvo - Centar za filozofiju medija i mediološka istraživanja, 2014.

Collins, R., Curran, J., Garnham, N., Scannell, Schlesinger, P., Sparks, C., ed. Media, Culture, and Society. London: Sage, 1986.

Davis, H. and Walton, P., ed. Language, Image, Media. Oxford: Blackwell, 1983.

Fairclough, N. L. Media Discourse. London: Edward Arnold, 1995.

Hall, S., Hobson, D., Lowe, A., Willis, P. ed. Culture, Media, Language. London: Hutchinson, 1980.

O'Keeffe, A. „Media and discourse analysis“. In The Routledge Handbook of Discourse Analysis, ed. J. Gee and M. Handford, 441-454. London: Routledge, 2011.

Pralica, D. "Analiza medijskog diskursa informativnog programa javnog radijskog servisa Vojvodine" [Media discourse analysis of informative program of the Public Radio Service of Voivodina]. Godišnjka Filozofskog fakulteta u Novom Sadu XXXIV, vol. 2 (2009): 83-94.

Savić, S. Diskurs analiza [Discourse analysis]. Novi Sad: Filozofski fakultet, 1993.

Spariosu, L. "Analiza diskursa radio-programa Javnog servisa Vojvodine na rumunskom jeziku" [Discourse analysis of radio program in the Romanian language of Public Broadcasting Service of Voivodina]. In Mediji o svakodnevici. Monitoring Javnog servisa Vojvodine i regionalnih televizija, ed. D. Valić-Nedeljković, 259-275. Novi Sad: Novosadska novinarska škola, 2008.

Valić-Nedeljković, D. "The Media in Serbia after the 5 October 2000 Changes." In Bulgaria Yugoslavia: Journalism in Intercultural Dialogue, ed. V. Roussanov, 10-14, 29-41. Sofia: ACCESS, 2002.

van Dijk, T. A. News as Discourse. Hillsdale, NJ: Erlbaum, 1988.

van Dijk, T. A. "Critical Discourse Analysis". In The Handbook of Discourse Analysis, ed. D. Schiffrin, D. Tannen, H. E. Hamilton, 352-371. Malden, Massachusetts, USA: Blackwell Publishers Ltd, 2005.

\section{Electronic sources}

http://www.blic.rs/

http://www.danas.rs/danasrs/iz_sata_u_sat/blic_najcitanija_novina_prema_najnovijem_istrazivanju.83 .html?news_id=84193 (accessed October 25, 2015)

http://www.kurir.rs/

http://www.novosti.rs/

\section{Acknowledgements}

This paper is part of the project No. III47020 Digitalne medijske tehnologije $i$ društveno-obrazovne promene "Digital Media Technologies and Socio-Educational Changes." 